\title{
Challenges of Indonesia's Decentralization Policy During the COVID-19 Pandemic
}

\author{
Kristian W. Wicaksono* \\ $\mathrm{PhD}$. Candidate at Political Science Department \\ Tunghai University \\ Taichung City, Taiwan \\ *kristian.widya@unpar.ac.id
}

\begin{abstract}
The purpose of this paper is to provide a review of the decentralization policy in Indonesia, particularly during the COVID-19 pandemic period. A systematic literature review is used in this paper. The data used is secondary data obtained on the internet network through tracking. The data is then qualitatively analyzed to answer research questions, namely, how to adjust decentralization policies to address the COVID-19 pandemic problem effectively. This study's conclusions show that the coordination and integration of central and regional government policies during the COVID-19 pandemic is essential. The central government and local government can complement each other to fully feel the government's existence for citizens.
\end{abstract}

Keywords—coordination, decentralization, integration, welfare

\section{INTRODUCTION}

Decentralization is a management technique in organizational management to increase an organization's effectiveness and efficiency by delegating authority from a higher level to a lower organizational structure. As far as effectiveness is concerned, the delegation of authority will help the organization achieve results in line with the objectives previously defined in the planning process because organizational levels that are in direct contact with the production of both goods and services have flexibility in terms of decision-making to respond to the organization's latest developments. Meanwhile, the transfer of authority in terms of efficiency will allow the organization to reduce the number of organizational resources and be more oriented towards its quantity and quality.

Decentralization can be understood at government organizations' level due to ongoing interactions between government agencies with structurally different positions, namely between high-level governments and those below. Understanding these interactions emphasizes the lower-level authorities' freedom to independently manage and run their government without profound interference from top-level government agencies. It is expected that decentralization will promote political stability, public services efficiency, poverty reduction, and justice in society.
Decentralization will suppress political instability, the feelings of disappointment in the regions against central government power's centralism, especially in the case of the central government dredging resources in the regions that have not been matched by the equal distribution welfare to the people in the regions. Thus, it is expected that decentralization will reduce political turmoil by revitalizing regional political institutions and processes.

Regarding public service delivery effectiveness, the appropriateness between public services and the Community's needs can be seen. It is hoped that with decentralization, the level of government in the regions can recognize and know the Community's needs more accurately. Thus, public services could respond to society's needs and are not viewed as merely the need for power.

Decentralization is also expected to alleviate poverty and increase justice in society. The transition of authority, especially in the financial sector, would enable regions to introduce creative poverty alleviation programs. Besides, the revenue redistribution function's circulation chain is shorter than the central government centralized fiscal management. It is intended to improve the responsiveness of government services to the needs of the vulnerable.

The decentralization policy in Indonesia, however, began to be challenged during the COVID-19 pandemic. The policy of disbursing assistance to citizens is economically affected by COVID-19 pandemic, which is not synchronous between the central and local governments. As discussed above, the policy of decentralization is a suitable choice for Indonesia's situation and conditions. It is because, geographically speaking, Indonesia is an archipelago nation. Then, each geographic region has its customs and traditions, so that the needs of each region are different. Also, Indonesia has a tradition of group disappointment in the regions against the central government as expressed in the PRRI-Parmesta Rebellion, the Westerling Rebellion, the RMS Rebellion, which was followed by the emergence of GAM in Aceh and, until now, some people in Papua through OPM still wants freedom. Therefore, this paper poses a question: how is the policy's adjustment to Indonesia's 
decentralization to cope effectively with the COVID-19 pandemic?

\section{LITERATURE REVIEW}

\section{A. The Decentralization Meaning}

Turner and Hulme stated that decentralization within the state includes a transfer of authority from an individual or entity in central government to any other person or agency that is 'closer' to the public to be served to perform any service to the public [1]. Turner and Hulme emphasize decentralization in terms of public service provision at different levels of government authority. So decentralization is carried out primarily based on the consideration of raising the provision of public services, particularly at the local level where the Community is directly in touch with the government so that these public services are provided.

Marcela said decentralization is how the central government transfers departments and municipalities to share powers, functions, and resources [2]. It aims to strengthen the government's sub-national levels' independence and promote active participation in local public affairs. Marcela's ideas clarify that the process of decentralization is the transfer of authority, functions, and resources from a higher government level (national level) to a lower level (Sub-National level). The goal is to enhance regional governments' autonomy and promote citizens' involvement in public affairs at the local level. From this view, it can be noted that there are three things which the central government submits to local governments, namely:

- The ability to make decisions efficiently and effectively to respond to the region's population's issues and public relations.

- Carrying out essential government functions, namely playing the government's roles and responsibilities as described in the state constitution at the local level for the Community so that the government's presence can be felt more realistically.

- Delegation of resources enables local councils to address local people's needs in light of their powers' capacity to provide public goods and carry out public service provision.

Barret, Mude, and Omiti claim that decentralization is transferred from central government to regional and local control through administrative, political, and fiscal authority [3]. It is stressed in the writings of Barret, Mude, and Omiti that the transition of decentralization authority is a package consisting of administrative decentralization, political decentralization, and fiscal decentralization. These three categories make decentralization a systematic and detailed management policy to strengthen government independence at the lower level in realizing governance to empower local communities.
According to Crawford and Hartmann, decentralization includes the transfer of authority, duties, and finance from central government to sub-national government levels at regional or local levels [4]. This understanding is consistent with Barret, Mude, and Omiti's previous opinion, which clarified that decentralization is a power delegation package involving three items: power, transparency, and funding from the central government to local governments.

According to Muttaqin, Duijn, Heyse, and Wittek, decentralization is characterized as a transfer of authority by which the central government transfers responsibility and specific functions to quasi-autonomous local government units that are outside its direct control [5]. This description confirms that the transition of authority is closely correlated with decentralization. This delegation is granted to both government and non-governmental actors and groups.

Moreover, Sutiyo and Maharjan said that decentralization is the central government's transition to its field organizations, state administrative units, semi-autonomous and parastatal organizations, local government or non-governmental organizations decision-making or administrative control [6]. This description explains that decentralization is interaction at various levels between two government entities. These relations include moving power to organizational units of the lower level of government.

Decentralization implementation has evolved quite rapidly. The process of decentralization and the growth of democratic local government is, empirically, a phenomenon that continues to expand and evolve in different countries-starting in Eastern Europe, from West Africa to South Asia, from Bolivia to Bulgaria. Countries in the region continue to shift greater power to regional governments and work more earnestly to provide services in their jurisdictions more productive and responsive to local governments.

There are at least three reasons which encourage decentralization to be implemented by several countries. First, decentralization was carried out because several countries anticipated the presence of a smaller government unit. This impulse occurs because a dictatorial system was historically the government regime in power and enforced a centralistic pattern of ties between governments.

The second purpose is to minimize the degree of authority that is too broad for the central government. In central government agencies, the large spectrum of powers allows the government administration's concentration to accumulate. It makes it impossible for the central government to function more openly, paying close attention to aspects of international trade and investment interactions in detail. The ability to undertake international trade and investment relations is wide open through the delegation of authority to regions so that these countries can enter the business arena more effectively.

Meanwhile, the third explanation is to promote community engagement at the local level in decision-making and increase transparency. As well as being expected to improve local 
institutions, decentralization can also promote community empowerment to more efficiently utilize their resources since the development agenda is intended to be more pro-poor in its development and focuses on a bottom-up approach to the pattern of community development. Since the 1990s, this trend has appeared to be symptomatic, especially in the design of poverty alleviation programs associated with implementing good governance to enhance the credibility, transparency, and responsiveness of government at the regional level.

From an administrative point of view, there are two factors behind the transition of power from the central government to local governments in the sense of decentralization. First, the territorial component is motivated by the desire to position authority in the territorial hierarchy at a lower government level and geographically closer to service providers (government agents) and service users (society). It is closely linked to the control period of the government. The government's real presence amid the people who live in some locations such as the outer islands or inland areas seems less warm, often with the vast territorial area. In this way, decentralization becomes a deadlock for the central government to reinforce this power scope and regain public recognition as an integral part of a particular region of the world.

Secondly, it relates to the functional element, namely the delegation to those technically specialized agents of authority. It is generally achieved in the sense of an abundance of particular industry areas, such as privatizing state-owned enterprises, to ease the state budget's pressure in terms of regular capital participation. Even as these state enterprises manufacture goods and services that many individuals require.

We may categorize the transition of power into three forms if analyzed more closely, namely:

- The delegation of power from the central government to regional governments is a delegation within the formal political framework.

- Delegation to public administration or related organizations at various levels, such as from the ministry at the central government level to the ministry's representative at the regional level.

- The shift of power, such as divestment, from a state entity to a non-government organization.

Some changes, particularly those related to the accountability aspect, are required to streamline the transfer of authority from the central government to regional governments or non-government actors. It is intended to ensure that the delegation of authority does not contribute to the regional government's development of violations and authority misuse. So that the central government can still ensure, as the initial authority, that the strategic objectives of decentralization implementation can still be achieved, significantly to improve the Community's welfare.

\section{B. Decentralization's Urgency and Benefits}

The transformation and involvement of the masses in formal political processes at the local level would support the government at both the national and local levels. According to Turner and Hulme, these advantages include [1]:

- Political education. Decentralization provides local communities with useful lessons to identify and appreciate disparities in policy priorities, natural selection and procedures for representatives, policy processes, regional planning and development, and the distribution and allocation of regional resources as expressed in regional budgets.

- Local politicians maturation. Decentralization facilitates the maturation of democratic leadership in the regions regarding policy development, the strengthening of grassroots political parties, and local politicians' capacity building in public budgeting. Capacitybuilding for local leaders will positively express the electorate's needs and promote political parties' circulation to position their cadres at the national level.

- The development of stability in politics. It is ensured through the involvement of local communities in the formal political arena, such as by the direct election of the head of local government, the active endorsement of political parties by the electorate in order to reinforce public faith in government and to generate social cohesion and a sense of community unity.

- Justice in politics. Significant political involvement is supposed to minimize the risk of undue concentration of power among a handful of political leaders. Political power can be spread more broadly such that decentralization becomes a process that can fulfil the needs of the oppressed poor and communities.

- Accountability. It will increase as local representation is more open to local citizens and closer to policy transparency and production achievement (results) than comparatively distant political leadership at the national level (or public services at the national level). Voting in municipal elections is a unique mechanism for local citizens to demonstrate satisfaction or disappointment with legislators' results.

- The government's responsiveness will improve because the delegation of power to the local government is the best option to effectively determine local needs' actual characteristics and their fulfilment from the financing angle.

Meanwhile, various problems are currently much better handled by the government administration's point of view regarding the transition of power from the central government to regional governments. In the following ways, the performance change is reflected: 
- Local specific plans may be prepared using comprehensive and up-to-date information for the local region that is only available locally.

- Inter-organizational coordination can be accomplished at the local level because the spectrum of coordination is not too broad.

- Via decentralization, experimentation and innovation can be fostered, thereby the opportunities for more successful development planning.

- Increased local government employee motivation because they are more accountable for the services they handle.

- Reducing the central government's overworked job to let go of repetitive decision-making and have more time at the national level to consider strategic problems, so that policy quality continues to improve.

\section{METHODS}

The author will first clarify the process employed in writing this paper before further explanation. A literature review is the analysis tool used in this article. This approach is based on researchers' efforts to compile and synthesize the related research findings that were done before [7].

In more depth, the literature survey process comprises three methods: a systematic approach, a semi-systematic approach, and an integrative approach. Using the first method, namely, systematic literature analysis, this paper will be presented. To generate new insights, this method seeks to synthesize and compare previous studies [7]. Through this, readers are supposed to determine how to adjust Indonesia's decentralization policy amid the COVID-19 pandemic.

The collected data is secondary data from a selection of many literary works that are important to this article. The data obtained were then qualitatively analyzed by evaluating the findings' consistency and strength from different studies and comparing the results of these studies [7].

\section{RESULTS AND DISCUSSION}

\section{A. Decentralization in Indonesia}

Essentially, since the period of the independence revolution (1945-1949) through the enactment of Law Number 1 of 1945 on the status of regional, national committees, attempts to carry out decentralization in Indonesia have been underway. Via Law Number 22 of 1948 on Regional Government, this policy was later revised. Then, at the beginning of the parliamentary democracy period (1950-1959) by Law No. 1 of 1957 on the Regions Principles of Government. The government exercised real autonomy during the revolution of independence and parliamentary democracy by granting local governments deeprooted discretion to handle their domestic affairs without intervention from the central government.
However, entering the era of Directed Democracy, by issuing Presidential Decree No. 6 of 1959, which was later adjudicated in Law No. 18 of 1965 concerning the Concepts of Regional Government, Soekarno carried out a recentralization of power and government management authority. Soekarno referred to decentralization as restricted autonomy, i.e., the legitimization of central government power over regional government administration.

This centralization persisted throughout the New Order period, while the concept of decentralization was repeated through Law Number 5 of 1974, but a centralistic growth trend with a top-down approach was evident in its implementation.

Decentralization has become a critical agenda at the beginning of the Reformation era and is carried out in response to people who want the benefits of progress to be felt equally for all Indonesian citizens. Precisely on 1 January 2001, by Law Number 22 the Year 1999, which was later updated into Law Number 32 the Year 2004 and Law Number 23 the year 2014, the Government of Indonesia formally enforced the Decentralization Program. In addition to addressing the governance aspect, decentralization also focuses on the financial management aspect through the Central and Regional Financial Balancing Act No. 25 of 1999, which was later amended into Law No. 33 of 2004.

These two policy products offer the Indonesian government new hope for implementing various governance management policies, both in political and administrative terms. On the political side, the decentralization policy provided the basis for the growth of democracy, which gave the government and local communities broader powers. In the meantime, the central government will reduce the administrative burden of transparency in delivering public services.

Three decentralization goals are illustrated in Law No 32 the Year 2004: (1) Increasing the welfare of the Community; (2) Increasing the quality of public services and (3) Enhancing competitiveness. When further analyzed, these three aims represent the highest expectations for local communities to be empowered so that the Indonesian people's general well-being can be felt.

\section{B. The Challenges of Indonesian Decentralization}

During the reform period, the introduction of decentralization ultimately brought a breath of fresh air for local governments to play a more realistic role among the citizens they safeguard. In theory, however, we should not close our eyes to the empirical challenges in Indonesia's implementation of decentralization. Several barriers had already emerged before the advent of problems in assisting people affected by COVID-19 pandemic.

In the first place, the introduction of controversial regional rules (Perda). The Ministry of Home Affairs released a list of 3,143 regional regulations that were cancelled or amended in 2016. It means that if decentralization is enforced from 2001 to 2016 , the total number of regional regulations cancelled will 
exceed 200 each year. The expenditure in making one Perda amounts to $\mathrm{Rp} 300$ million, according to the Ministry of Finance. The wasteful usage of resources has surpassed Rp. 9,429 billion if 3,143 complex regional regulations have been cancelled as required in Law Number 23 of 2014, this inefficiency reflects that the regions' legal goods have not led citizens to increased welfare.

Second, there is a greater allocation of the regional budget for personnel expenditure. Approximately $70 \%$ of the regional expenditure budget is devoted to staff spending needs. Around 120 local governments in Indonesia are currently threatened with bankruptcy because their original regional income (PAD) cannot meet budget needs. According to data from the Ministry of Home Affairs, if averaged, it is known that PAD can meet only about $5 \%$ of the budget needs, the remainder depends on the General Allocation Fund (DAU) and the Special Allocation Fund (DAK), which are disbursed by the central government. According to the Ministry of Finance, the central government must allocate the cumulative DAU in 2019, 2020, and 2021 are Rp. 417.8 trillion, Rp. 427 trillion, and Rp. 390,29 trillion. It indicates that, despite the COVID-19 pandemic, in terms of funding for regional finances, the pressure on the central government's budget has not decreased.

Third, the geographic expansion euphoria. Based on data submitted by the Ministry of Home Affairs' Regional Autonomy Advisory Council (DPOD), it is known that 205 New Autonomous Regions (DOBs) were established over the ten years from 1999 to 2009, covering seven provinces, 164 regencies and 34 cities. Currently, 524 regions consisting of 34 provinces, 398 districts and 93 cities are the number of autonomous regions in Indonesia, except the six administrative regions in DKI Jakarta. Pemekaran's proliferation is quite a burden on the state budget. According to the Ministry of Finance, allocation of DAU of in 2003 for 22 new autonomous regions is $\mathrm{Rp}$ 1,33 trillion. Then, in 2004 the allocation for 40 new autonomous regions is Rp. 2,6 trillion and in 2010 is Rp. 47.9 trillion. Due to the weak financial ability of new autonomous regions, the burden of the APBN is growing, including the provision of a Special Allocation Fund (DAK) to finance the growth of infrastructure.

As a consequence of the restricted tax authority, the fourth problem is the low regional revenue collection. It should be noted that Indonesia's new fiscal decentralization is not working optimally. Just a handful of service operations and the provision of public goods are delegated to regional governments, while, on the revenue side, there are still many strategic taxes raised by the central government, such as income taxes. Consequently, by focusing on local tax sources, local councils have not entirely fulfilled their budget needs.

The fifth is linked to national development integration, both in terms of development planning and implementation. As a consequence of the immediate regional head election process, this happens. It is difficult for the central government to integrate the National Medium-Term Development Plan (RPJMN), the program offered when the President campaigns for the Regional Medium-Term Development Plan (RPJMD), which is proposed during the campaign of the Regional Head. The regional heads have their development plans. It is especially true from a political point of view, namely the history of each Regional Head and the President's political parties. Consequently, many development programs are challenging for the government to harmonize due to each side's distinct directions and policy principles.

The sixth is the question of local government officials readiness to carry out the authority they have. During the New Order government, the centralized government structure made the ordinary regional government machinery dependent upon the central government. Since local government officials were accustomed to only receiving the central government's command during the New Order period, the central government issued all the policy implementation criteria beginning from the budget, implementation guidelines and technical guidance. As a result of local government authorities low ability, this can be seen in collapsed school buildings and sluggish flood control. Not to mention the regional capacity issue of preparing financial reports in compliance with the financial reporting standards laid down by the Ministry of Home Affairs. So far, not all municipal governments have prepared financial reports according to the requirements available.

The seventh is an issue connected with the disparity in development between regions. It begins between urban and rural areas, and then between Indonesia's western part and Indonesia's eastern part. Then there is a difference between growth on the island of Java and growth beyond the island of Java. As well as the slow growth in the country's border areas and Indonesia's outer islands. Until now, this problem has become a question of development inequality, leading regions in different regions to believe that the introduction of regional autonomy has not provided justice to the population in its entirety.

Eighth, by further strengthening the government bureaucracy by additional roles and organizations within the central government, the central government has a problem linked to recentralization. One that has recently drawn media attention is the inclusion of ministerial-level vacancies, namely the position of deputy minister. While Indonesia has several ministries, namely 34 ministries, it is one country. This figure is more than twice the number of ministries that only 15 ministries have in the United States. So that the position of deputy minister gradually makes the central government bureaucracy grow fat. It is ironic because Indonesia is implementing decentralization, which is mainly reinforcing local government-level bureaucracy.

Issues started to surface during the COVID-19 pandemic that the central government was gradually aiming at centralization rather than systematically enforcing decentralization. The publication of the Omnibus Law on Investment and Jobs shows one of them. It is alleged that this law has undermined local governments' position. Moreover, as 
previously discussed, the distribution of economic assistance to people affected by the COVID-19 pandemic has also been hindered, owing to poor cooperation between the central and regional governments.

\section{CONCLUSION}

Based on the above discussion, it is understood that the introduction of decentralization policies in Indonesia has encountered a range of problems. Owing to the advent of the COVID-19 pandemic, this issue has been gradually posed. Various guidelines can be used as a framework for addressing Indonesia's decentralization problems. First, it is essential to explain the division of authority between the two local government levels, namely the Regional Government and Regencies/Municipalities Government. To prevent conflicting responsibilities and double funding, this must be governed legally so that there is consistency in the distribution of jurisdiction between the two government levels to be responsible for various local strategic services. It also concerns how the central government and local governments collect the list of persons who need assistance. Due to the COVID-19 pandemic, coordination down to the village level could be carried out to compile economic assistance data.

Moreover, the COVID-19 pandemic also brings blessings, even though it brings difficulties. It is because a lot of public administration related work is done using information and communication technology. With the growing use of this technology, the Central and Regional Governments have made efforts to make all data and services accessible online so that the convergence of data and services can also be realized faster.

Secondly, there should be adequate assets, budgets and reserve funds for the regions receiving authority delegation. The ability to collect its revenue should also support this, as long as this is following the substance of the authority they have. In the context of a country implementing a decentralization policy, strengthening local governments' tax collection capacity is an inevitable consequence. Therefore, the distribution of tax collection authority between the Central Government, the Provincial Governments, and the Regencies/Municipalities Governments must be reconsidered. The decentralization line that directly contacts the Community should be left with strategic taxes so that the decentralization policy can provide tangible benefits and effects to improve the Community's welfare.

Third, competent government officials have to be employed by local governments. It means that, for reasons of professionalism and work efficiency, local government officials should be recruited through a merit system (a system that is following regulations), fired if they are not competent, transferred to another job and promoted according to their tenure and performance. Therefore, within the local government, the civil service reform program should be organized systematically and rationally. In determining this process, regional civil service bodies must play an essential role in ensuring that the civil service mechanism can be implemented fairly and transparently to create a reliable local government organization.

Fourth, reinforcing the legislative bodies elected by local communities to operate the parties' policy lines, decide policies, and determine internal procedures within their parties. The weak capacity of regional legislative institutions to produce regional quality regulations is one of the causes behind the issuance of complex regional regulations. Therefore, political parties' political recruitment should be improved to account for their cadres' quality which will later be placed in the legislative body. On the other hand, concerning the Omnibus Law on Manpower and Investment and other laws, harmonizing laws relating to local governments also needs to be carried out. Thus, the need for the Omnibus Law of Central and Regional Government can probably be considered by the Central Government and the House of Representatives (DPR$\mathrm{RI})$.

Fifth, the central government's administration should solely serve external advisers and inspectors and not play a strategic role in the local authority. Therefore, strengthening local government institutions must be a priority by streamlining the central government structure and effectively implementing work specialization at the local government level.

Thus, it can be concluded that Indonesia's decentralization policy needs to be continued despite a range of challenges. In reality, the COVID-19 pandemic offers a beneficial lesson on how to continually strengthen and establish cooperation and integration between the Central and Regional Governments. The central government and local government can complement each other to feel the government's existence and increase public welfare fully.

\section{REFERENCES}

[1] M. Turner and D. Hulme, Governance, Administration, and Development: Making the State Work, New York: Palgrave, 1997.

[2] C. M. Medina, "Local Autonomy, Social Control: Decentralization As A Strategy For Government Legitimacy," en Hemisphere, vol. 2, no. 1, pp. 31-34, 2002.

[3] C. B. Barrett, A. G. Mude and J. M. Omiti, "Decentralization and the Social Economics of Development: An Overview of Concepts and Evidence from Kenya," in Decentralization and the Social Economics of Development: Lessons From Kenya, Pondicherry, CAB International, 2007, pp. 1-12

[4] G. Crawford and C. Hartmann, "Introduction: Decentralization as a Pathway out of Poverty and Conflict?," in Decentralization: A Pathway out of Poverty and Conflict?, Amsterdam, Amsterdam University Press, 2011, pp. 7-32.

[5] T. Muttaqin, M. van Duijn, L. Heyse and R. Wittek, "The Impact of Decentralization on Educational Attainment in Indonesia," in Decentralization and Governance in Indonesia, New York, Springer, 2016, pp. 79-104.

[6] S. Sutiyo and K. L. Maharjan, Decentralization and Rural Development in Indonesia, Singapore: Springer, 2017.

[7] H. Snyder, "Literature review as a research methodology: An overview and guidelines," Journal of Business Research, vol. 104, no. 1, pp. 333$339,2019$. 